\title{
Narrative Ethics
}

Thomas J. Wilson Prize

The Board of Syndics of Harvard University Press has awarded this book the twenty-fourth annual Thomas J. Wilson Prize, honoring the late director of the Press. The Prize is awarded to the book chosen by the Syndics as the best first book accepted by the Press during the calendar year. 



\section{Narrative Ethics}

Adam Zachary Newton

Harvard University Press

Cambridge, Massachusetts

London, England 
Copyright $\odot 1995$ by the President and Fellows of Harvard College All rights reserved

Printed in the United States of America

Second printing, 1997

First Harvard University Press paperback edition, 1997

LIBRARY OF CONGRESS CATALOGING-IN-PUBLICATION DATA

Newton, Adam Zachary.

Narrative ethics / Adam Zachary Newton.

p. $\mathrm{cm}$.

Includes bibliographical references and index.

ISBN 0-674-60087-8 (cloth)

ISBN 0-674-60088-6 (pbk.)

1. Ethics in literature. 2. Fiction-Moral and ethical aspects.

3. Philosophy, Modern-20th century. 4. Ethics, Modern-20th century.

5. Narration (Rhetoric). 6. American fiction-History and criticism-Theory, etc.

7. English literature-History and criticism-Theory, etc.

PN49.N52 1995

$809.3^{\prime} 9353-\mathrm{dc} 20$

94-19710 


\section{To my mother and my father}

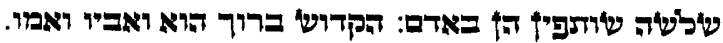

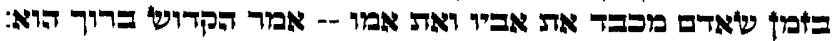
מעלה אני עליהם כאילו דרתי ביליהם וכבדוציו

Kiddushin $30 \mathrm{~b}$

ויעש=" יצחק ויחפר אית בארת המים

Genesis 26:18

אשיר חפרו בימי אברהם אביו. 
